\title{
Modeling Approach with Box-Behnken Design for Optimization of Pb Bioaccumulation Parameters in Gammarus pulex (L., 1758)
}

\author{
Aysegul Pala ${ }^{a}$, Osman Serdar ${ }^{a}, *$, Muharrem Ince $^{\mathrm{b}, \mathrm{d}}$, and Ali Onal ${ }^{\mathrm{c}}$ \\ ${ }^{a}$ Munzur University, Faculty of Fisheries, 62000 Tunceli, Turkey \\ b Munzur University, Faculty of Engineering, Department of Chemical Engineering, 62000 Tunceli, Turkey \\ ${ }^{c}$ Munzur University, Faculty of Engineering, Department of Food Engineering, 6200 Tunceli, Turkey \\ d Munzur University Rare Earth Elements Research and Application Center, 62000 Tunceli, Turkey
}

\section{INTRODUCTION}

Pollution of the aquatic systems is a severe environmental problem and due mostly to anthropogenic activities $(1,2)$. Industrial contaminants, especially heavy metals, are toxic and pose a serial risk to human health and the aquatic flora and fauna (3). Heavy metals such as cadmium, copper, and lead do not decompose in the environment, so their concentrations must be monitored to admissible levels (4). Lead is hazardous even at trace levels, is used in industrial processes including paints and leaded gasoline, glass and batteries $(5,3,6)$, and can lead to disorders of the liver, kidneys, heart, in addition to severe damage to erythrocytes and leucocytes resulting in susceptibility to infections $(7,8)$.

To evaluate the potential human influence on the ecosystems, heavy metals bioaccumulation strategies as well as concentrations of chemicals in organisms of the aquatic systems and their levels have to be well established (9). This depends on some important parameters including biological species and the element type, measure of exposure time to accumulation, and the development of an adequate experimental design on different spatial and temporal scales (10-13). Aquatic organisms exposed to chronic contamination accumulate metals directly via water or via their diet. In biological tissues, metals analysis

\footnotetext{
*Corresponding author.

E-mail: oserdar@munzur.edu.tr

Tel: +904282131794/2541

Fax: +904282131624
}

\section{ABSTRACT}

The aim of this research was to evaluate the suitability of Gammarus pulex (L., 1758), an amphipod crustacean, as a biomonitor for lead $(\mathrm{Pb})$. A BoxBehnken experimental approach combined with response surface modeling (RSM) and quadratic programming was employed to increase the knowledge about $\mathrm{Pb}^{2+}$ bioaccumulation in Gammarus pulex (L., 1758). Independent variables, such as temperature ranging from 18 to $22{ }^{\circ} \mathrm{C}$, contact time from 8 to 48 hours, and $\mathrm{Pb}^{2+}$ ion solution concentrations from 50 to $100 \mu \mathrm{g} \mathrm{L}^{-1}$, were studied and tested using analysis of variance (ANOVA). The standardized effects of the independent variables and their interactions on the dependent variable were also investigated according to a Pareto chart. The selected variables' optimum values were obtained by solving the quadratic regression model along with analyzing the response surface contour plots. Optimum experimental conditions were obtained at $\mathbf{2 2 . 0}$ ${ }^{\circ} \mathrm{C}$, contact time of 8 hours, and $\mathrm{Pb}$ concentration at $69.5 \mu \mathrm{g} \mathrm{\textrm {L } ^ { - 1 }}$. Based on the Box-Behnken design, the applied model is significant because the model F-value and $\mathrm{R}^{2}$ were obtained at 77.80 and 0.9901 , respectively. Bioaccumulation of $\mathrm{Pb}$ was determined using electrothermal atomic absorption spectrometry (ETAAS). The obtained data suggest that $G$. pulex can be used as a $\mathrm{Pb}$ biomonitor.

is thus relevant to keep the bioavailable fraction of metals potentially toxic for the aquatic animals under observation. In fact, the bioaccumu- lation process completes the ability of organisms to regulate metals and the effects of water chemistry on metal bioavailability $(14,15)$. Among potential biomonitors, many researchers have recently focused on the genus Gammarus pulex (L., 1758), an amphipod crustacean, for the study of inorganic and organic pollutants in establishing the quality of the environment $(16,17)$ as well as its important ecological role and usage for ecotoxicological research. These organisms are commonly found and are important components of marine, freshwater and brackish water, and play a vital role in the aquatic food webs, and can be easily used for experimental studies. Furthermore, gammarids, due to their ability to accumulate metals, are interesting organisms for the development of bio-indicator systems and for biological observation $(18,19)$. They are also suitable candidates for the development of exposure biomarkers because metal accumulation can induce their sublethal alterations in terms of physiological, biochemical, and behavioral levels $(20,21)$. Recently, several models. including biologically-based, have been proposed to evaluate metal bioaccumulation $(22,23)$. These predictive models are generally constructed in the laboratory by establishing kinetic parameters describing physiological mechanisms involved in the uptake of bio-available metals and elimination of bio-accumulated metals. Some biodynamic approaches were successfully carried out in various aquatic species, especially the gammarids (24-29). Several researchers have reported that the amount of metal measured 
in some aquatic organisms depends on body size for the determination and evaluation of bio-concentration factors (30). Generally, there are three possible mechanisms for metal intake such as passive transport, active uptake, and specific cellular uptake (31).

In several studies, invertebrates from freshwater have been used for aquatic toxicology studies on heavy metals toxic effects by assaying enzyme activities and histologic changes. For example, $\mathrm{Pb}, \mathrm{Cd}$, and $\mathrm{Cu}$ in the gills of Mytilus galloprovincialis were used as a biomarker in investigating the single and combined effects of heavy metal pollution in terms of biochemistry (32). In another study, physiological and behavioral effects were investigated for the single and combined administration of $\mathrm{Cd}$ and $\mathrm{AsO}_{4}^{-3}$ in $G$. pulex (33). Also, the effect of $\mathrm{Cd}$, $\mathrm{Ni}$, and $\mathrm{Pb}$ on the intracellular effect of G. fossarum was studied by comparative methods (34).

In the present study, G. pulex was selected as a bioindicator organism to determine aquatic pollution in terms of $\mathrm{Pb}$ sensitivity in freshwater systems. This study focuses on the experimental parameters with $\mathrm{Pb}$ bioaccumulation in gammarids using the Box-Behnken design methodology as a tool to assess and verify bioaccumulation. To our knowledge, no studies have been published using the BoxBehnken experimental design and RSM (Response Surface Modeling) for modeling of $\mathrm{Pb}^{2+}$ ion bioaccumulation in G. pulex.

Classical and conventional methods cannot depict all combinations that affect an experiment. At the same time, these methods require much time to obtain the optimum levels. Using a statistical experimental design, which optimizes all of the effecting parameters collectively, these limitations can be eliminated. For modeling of process parameters, RSM contains a small number of experiments and is, therefore, widely used in various processes. The primary target of RSM is to detect the optimum operational conditions for the system or to detect a region that compensates the operating specifications (35, 36). In this study, the influence of some operating variables, including solution temperature, contact time, and solution lead ion concentration, was investigated.

\section{EXPERIMENTAL}

\section{Reagents and Standard Solutions}

The chemicals used were of analytical grade and obtained from Merck (Darmstadt, Germany). A stock solution of $1000 \mathrm{mg} \mathrm{L}^{-1}$ $\mathrm{Pb}^{2+}$ was prepared by dissolving an accurate quantity in ultrapure water acidified with $0.5 \mathrm{M} \mathrm{HNO}_{3}$. All other concentrations were prepared using the stock solutions by dilution.

\section{Collecting and Storing of Samples}

Individuals of the G. pulex organisms were collected with dip nets from the Munzur River $(39.156820 \mathrm{~N}, 39.499640 \mathrm{E})$ in Tunceli, Turkey. The samples were kept in plastic bottles with screw tops with holes so oxygen can flow into them, then filled with river water, and immediately brought to the laboratory. These organisms were stored in a stock aquarium for at least 15 days in a climate-controlled room at $18 \pm 0.5^{\circ} \mathrm{C}$ and a $12: 12$ light:dark cycle. They were fed on refuted willow leaves and checked every 24 hours. For this purpose, experimental groups were constructed in which different concentrations of $\mathrm{Pb}$ (ranging from $50 \mu \mathrm{g} \mathrm{L}^{-1}$ to $100 \mu \mathrm{g} \mathrm{L}^{-1}$ ) were applied to $G$. pulex under various temperatures (ranging from $18{ }^{\circ} \mathrm{C}$ to $22^{\circ} \mathrm{C}$ ) for periods of time ranging from 8 to 48 hours.

\section{Atomic Apectroscopy $\bigcirc$ Vol. 40(3), May/June 2019}

\section{Application of Lead Solution to Gammarus pulex (L., 1758)}

First, the acute toxicity (LC50) values (about $150 \mathrm{ppm}$ ) of $\mathrm{Pb}$ were determined according to static nonrenewal tests (37) in the organisms. Three different sublethal concentrations (50, 75, and $100 \mathrm{ppm}$ ) lower than the LC50 value were determined. Experiments were carried out in one-liter glass bottles. For each experimental group, 30 organisms were added to each bottle and the trials carried out in three replicates.

\section{Box-Behnken Experimental Design and Optimization by RSM}

The optimum conditions for $\mathrm{Pb}^{2+}$ bioaccumulation by $G$. pulex were determined by means of a three-factor, three-level Box-Behnken experimental design, combined with RSM and quadratic programming. According to single-factor experiments, a Box-Behnken design was used to determine three independent variables: temperature $\left(\mathrm{X}_{1}\right), \mathrm{Pb}$ concentration $\left(\mathrm{X}_{2}\right)$, and contact time $\left(\mathrm{X}_{3}\right)$ on bioaccumulation of $\mathrm{Pb}^{2+}$ by G. pulex (Y). In order to reduce unexplained variability effects on the observed response, randomized experimental order was carried out. Seventeen experimental points including replications of the central points experimental design were used. Table I lists the different parameters such as variable conditions, run order, experimental values, and predicted values. A final equation was obtained from RSM in terms of actual factors by using the following equation:

Eq. 1

$$
\begin{aligned}
& \mathrm{Y}=+76192.34-9810.03 \mathrm{X}_{1}+261.16 \mathrm{X}_{2}+ \\
& 824.16 \mathrm{X}_{3}-3.71 \mathrm{X}_{1} \mathrm{X}_{2}-49.86 \mathrm{X}_{1} \mathrm{X}_{3}+ \\
& 0.21 \mathrm{X}_{2} \mathrm{X}_{3}+289.58 \mathrm{X}_{1}{ }^{2}-0.31 \mathrm{X}_{2}^{2}+2.50 \mathrm{X}_{3}^{2}
\end{aligned}
$$

After data analysis by ANOVA in order to determine the lack of fit, other parameters were evaluated including the effects of quadratic, 
linear, and interaction variables for bioaccumulation of $\mathrm{Pb}^{2+}$ by $G$. pulex. Response surface modeling and data analyses were carried out with Design Expert software program (Design Expert Version 10, Stat-Ease, USA). All bioaccumulation experiments were performed in flasks containing $\mathrm{Pb}^{2+}$ ion synthetic solutions under parameters affecting accumulation, including temperature $\left(18-22^{\circ} \mathrm{C}\right), \mathrm{Pb}$ concentration (50-100 $\mathrm{g} \mathrm{L}^{-1}$ ) and contact time ( 8 to 48 hours). The G. pulex were separated from the aquatic medium by filtering and digesting in a microwave digestion system (Coolpex, P.R. China). The microwave digestion program is listed in Table II. Clear solutions were analyzed using the AAnalyst ${ }^{\mathrm{TM}}$ 800 ETAAS for $\mathrm{Pb}$ determination (PerkinElmer, Inc., Shelton, CT, USA). The operating conditions are listed in Table III. In this study, an EDL was not used because it generates much more light intensity than the HCL, which has short warm-up times and better stability.

\section{RESULTS AND DISCUSSION}

\section{Second-order Polynomial Model}

Response surface modeling with a Box-Behnken design and ANOVA was used for $\mathrm{Pb} 2+$ bioaccumulation by $G$. pulex and the parameters are given in Table I and Table IV, respectively. The Model F-value of 77.80 shows that the model is significant. The probability that an Fvalue of this magnitude can occur due to noise is $0.01 \%$. Values less than 0.05 of "Probe $>F$ " indicate statistical significance of model terms. Because the model coefficient (R2) was 0.9901 , it can be said that $99.01 \%$ of the model-predicted values matched the experimental bioaccumulated $\mathrm{Pb}$ values in G. pulex. The "Pred R-Squared" of 0.8670 is in reasonable agreement with the "Adj R-Squared" of 0.9774 ; i.e., the difference is less than 0.2. "Adeq Precision" measures
TABLE I

Box-Behnken Design and Observed Responses of $\mathrm{Pb}^{2+}$ Bioaccumulation $\left(\mu \mathrm{g} \mathrm{\textrm {g } ^ { - 1 }}\right)$

\begin{tabular}{ccccc}
\hline Run & Temp. & $\begin{array}{c}\text { Pb Con- } \\
\text { centration }\end{array}$ & $\begin{array}{c}\text { Contact } \\
\text { Time }\end{array}$ & $\begin{array}{c}\mathrm{Pb} \\
\left(\mathrm{qe}, \mu \mathrm{g} \mathrm{g}^{-1}\right)\end{array}$ \\
\hline 1 & $\mathrm{X}_{1}\left({ }^{\circ} \mathrm{C}\right)$ & $\mathrm{X}_{2}\left(\mu \mathrm{g} \mathrm{L}^{-1}\right)$ & $\mathrm{X}_{3}$ (hour) & Observed \\
2 & 20 & 100 & 8 & 314 \\
3 & 18 & 100 & 28 & 395 \\
4 & 20 & 100 & 48 & 143 \\
5 & 20 & 75 & 28 & 140 \\
6 & 18 & 75 & 48 & 3456 \\
7 & 18 & 75 & 8 & 450 \\
8 & 20 & 75 & 28 & 0 \\
9 & 20 & 75 & 28 & 35 \\
10 & 22 & 75 & 48 & 221 \\
11 & 18 & 50 & 28 & 252 \\
12 & 22 & 100 & 28 & 0 \\
13 & 20 & 75 & 28 & 5006 \\
14 & 22 & 75 & 8 & 254 \\
15 & 20 & 75 & 28 & 596 \\
16 & 20 & 50 & 48 & 0 \\
17 & 20 & 50 & 28 & 819 \\
\hline & 22 & 50 & & \\
\hline
\end{tabular}

TABLE II

G. pulex Sample Digestion Method

\begin{tabular}{lclcccc}
\hline $\begin{array}{l}\text { Biological } \\
\text { Sample }\end{array}$ & $\begin{array}{c}\text { Weight } \\
(\mathrm{g})\end{array}$ & Solvent & $\begin{array}{c}\text { Volume } \\
(\mathrm{mL})\end{array}$ & $\begin{array}{c}\text { Temp. } \\
\left({ }^{\circ} \mathrm{C}\right)\end{array}$ & $\begin{array}{c}\text { Pressure } \\
(\text { atm })\end{array}$ & $\begin{array}{c}\text { Time } \\
(\mathrm{min})\end{array}$ \\
\hline G. pulex & 0.2 & $\mathrm{HNO}_{3}$ & 4 & 150 & 15 & 4 \\
& & $\mathrm{H}_{2} \mathrm{O}_{2}$ & 1 & 180 & 25 & 5 \\
\hline
\end{tabular}

TABLE III

Instrumental Operating Conditions of AAnalyst 800 ETAAS

\begin{tabular}{lrrr}
\hline Step & $\begin{array}{c}\text { Temp. } \\
\left({ }^{\circ} \mathrm{C}\right)\end{array}$ & $\begin{array}{r}\text { Ramp Time } \\
(\mathrm{s})\end{array}$ & $\begin{array}{c}\text { Hold Time } \\
(\mathrm{s})\end{array}$ \\
\hline Dry 1 & 110 & 1 & 30 \\
Dry 2 & 140 & 15 & 30 \\
Pyrolysis & 850 & 10 & 20 \\
Atomization & 1600 & 0 & 5 \\
Clean-out & 2450 & 1 & 3 \\
\hline Wavelength & $283.3 \mathrm{~nm}$ & \\
Hollow cathode lamp current & $440 \mathrm{~mA}$ & & \\
Background correction & Zeeman-effect & & \\
Injection volume & $20 \mu \mathrm{L}$ \\
Slit width & $0.7 \mathrm{~nm}$ & \\
\hline
\end{tabular}




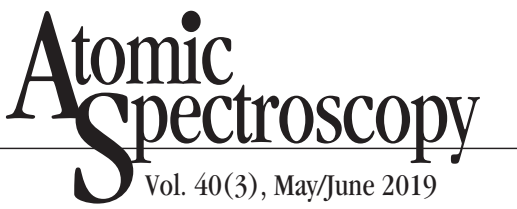

the signal-to-noise ratio. A ratio greater than 4 is desirable. The ratio of 30.890 obtained in this study indicates an adequate signal. This model can be used to navigate the design space. On the other hand, Ince and Kaplan Ince (38) reported that when $R^{2}>0.75$, the model is adequate. This study revealed that the lack of fit that measures the fitness of the model was not significant $(P>0.05)$; the "Lack of Fit F-value" of 6.17 implies that the Lack of Fit is not significant relative to pure error. There is a $5.56 \%$ chance that a "Lack of Fit Fvalue" this large could occur due to noise. A non-significant lack of fit is good. In addition, the number of experiments was sufficient to determine the effects of the independent variables for $\mathrm{Pb}$ bioaccumulated values in $G$. pulex. The results expressed by using the statistical model were adequate in order to predict the $\mathrm{Pb}$ levels and fitted to a second-order polynomial equation. In this case, while $\mathrm{X}_{3}, \mathrm{X}_{1}^{2}, \mathrm{X}_{2}^{2}, \mathrm{X}_{3}^{2}$, and $\mathrm{X}_{1} \mathrm{X}_{3}$ are highly significant $(\mathrm{P}<0.01), \mathrm{X}_{1}, \mathrm{X}_{2}, \mathrm{X}_{1} \mathrm{X}_{2}, \mathrm{X}_{2} \mathrm{X}_{3}$, they are significant model terms in terms of $\mathrm{Pb}$ bioaccumulation values in $G$. pulex. The quadratic and linear coefficients affecting the factors on the response of $\mathrm{Pb}$ bioaccumulation in G. pulex follow the order of contact time $>$ temperature $>\mathrm{Pb}$ concentration.

\section{RSM Analysis}

Contour plots (2D) and response surface plots (3D) were presented because they are useful in determining maximum, middle, and minimum response points. With contour plots, the level of the variables can be determined and also contribute to a desired response; in addition, the variables' levels are plotted in a curve with equal response. Because of these reasons, contour plots are easier to interpret. Figure 1 shows the effect of $\mathrm{Pb}$ concentration and temperature on $\mathrm{Pb}$ bioaccumulation in G. pulex.

TABLE IV

Analysis of Variance (ANOVA) for the Quadratic Polynomial Mode

\begin{tabular}{|c|c|c|c|c|c|c|}
\hline Source & $\begin{array}{l}\text { Sum of } \\
\text { Squares }\end{array}$ & df & $\begin{array}{c}\text { Mean } \\
\text { Square }\end{array}$ & $\begin{array}{c}\mathrm{F} \\
\text { Value }\end{array}$ & $\begin{array}{l}\text { p-value } \\
\text { Prob > F }\end{array}$ & \\
\hline Model & $2.982 \mathrm{E}+007$ & 9 & $3.314 \mathrm{E}+006$ & 77.80 & $<0.0001$ & $\begin{array}{l}\text { Signifi } \\
\text { cant }\end{array}$ \\
\hline $\mathrm{X}_{1}$-Temp. & $3.160 \mathrm{E}+005$ & 1 & $3.160 \mathrm{E}+005$ & 7.42 & 0.0296 & \\
\hline $\mathrm{X}_{2}$-Lead conc. & 35431.22 & 1 & 35431.22 & 0.83 & 0.3920 & \\
\hline $\begin{array}{l}\mathrm{X}_{3} \text {-Contact } \\
\text { time }\end{array}$ & $9.333 \mathrm{E}+005$ & 1 & $9.333 \mathrm{E}+005$ & 21.91 & 0.0023 & \\
\hline $\mathrm{X}_{1} \mathrm{X}_{2}$ & $1.373 \mathrm{E}+005$ & 1 & $1.373 \mathrm{E}+005$ & 3.22 & 0.1157 & \\
\hline $\mathrm{X}_{1} \mathrm{X}_{3}$ & $1.591 \mathrm{E}+007$ & 1 & $1.591 \mathrm{E}+007$ & 373.52 & $<0.0001$ & \\
\hline $\mathrm{X}_{2} \mathrm{X}_{3}$ & 45071.29 & 1 & 45071.29 & 1.06 & 0.3378 & \\
\hline $\mathrm{X}_{1}^{2}$ & $5.649 \mathrm{E}+006$ & 1 & $5.649 \mathrm{E}+006$ & 132.65 & $<0.0001$ & \\
\hline $\mathrm{X}_{2}^{2}$ & $2.799 \mathrm{E}+006$ & 1 & $2.799 \mathrm{E}+006$ & 65.71 & $<0.0001$ & \\
\hline $\mathrm{X}_{3}^{2}$ & $4.208 E+006$ & 1 & $4.208 E+006$ & 98.81 & $<0.0001$ & \\
\hline Residual & $2.981 \mathrm{E}+005$ & 7 & 42589.66 & & & \\
\hline Lack of Fit & $2.451 \mathrm{E}+005$ & 3 & 81706.61 & 6.17 & 0.0556 & $\begin{array}{l}\text { Not sig- } \\
\text { nificant }\end{array}$ \\
\hline Pure Error & 53007.80 & 4 & 13251.95 & & & \\
\hline R-Squared & 0.9901 & & & & & \\
\hline Adj R-Squared & 0.9774 & & & & & \\
\hline Pred R-Squared & 0.8670 & & & & & \\
\hline
\end{tabular}

${ }^{*} \mathrm{P}<0.01$ highly significant; $0.01<\mathrm{P}<0.05$ significant; $\mathrm{P}>0.05$ not significant.

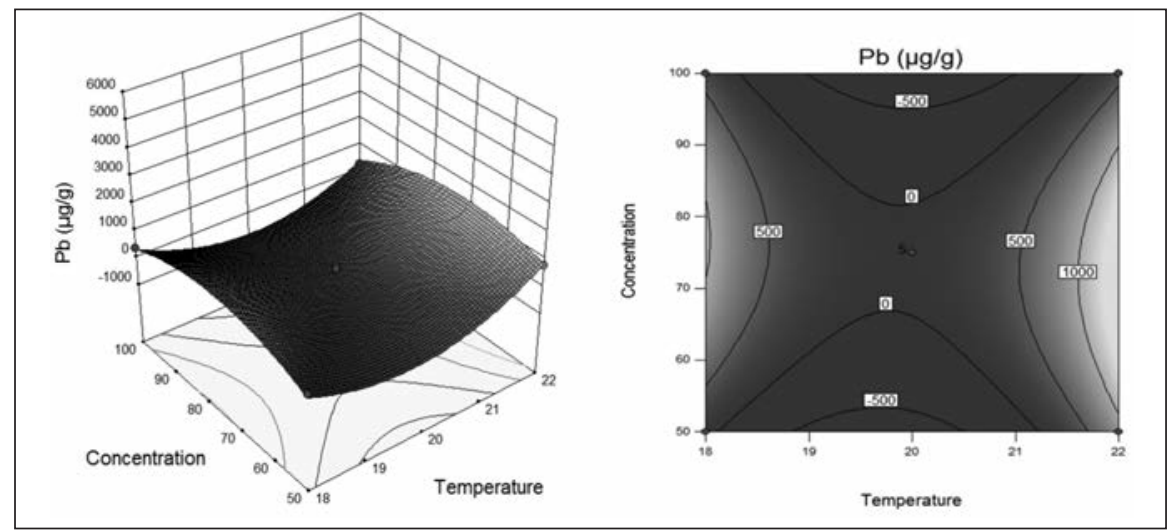

Fig 1. Effects of Pb concentration and temperature on Pb bioaccumulation.

The bioaccumulated $\mathrm{Pb}$ amount increased with an increase in temperature until it reaches $22^{\circ} \mathrm{C}$, indicating that there are further improvements for bioaccumulation of the $\mathrm{Pb}$ levels. At the same time, contact time has important effects on $\mathrm{Pb}$ bioaccumulation in G. pulex. The effects of contact time and temperature on $\mathrm{Pb}$ bioaccumula- tion in G. pulex are shown in Figure 2. The interaction of these two variables had a significant effect on the adsorption process, including from the quadratic variables (contact time, $\mathrm{P}<0.01$; temperature $\mathrm{P}<0.05$ ). As a result, the impact of contact time on the bioaccumulation level was more significant than the temperature. The effects of 


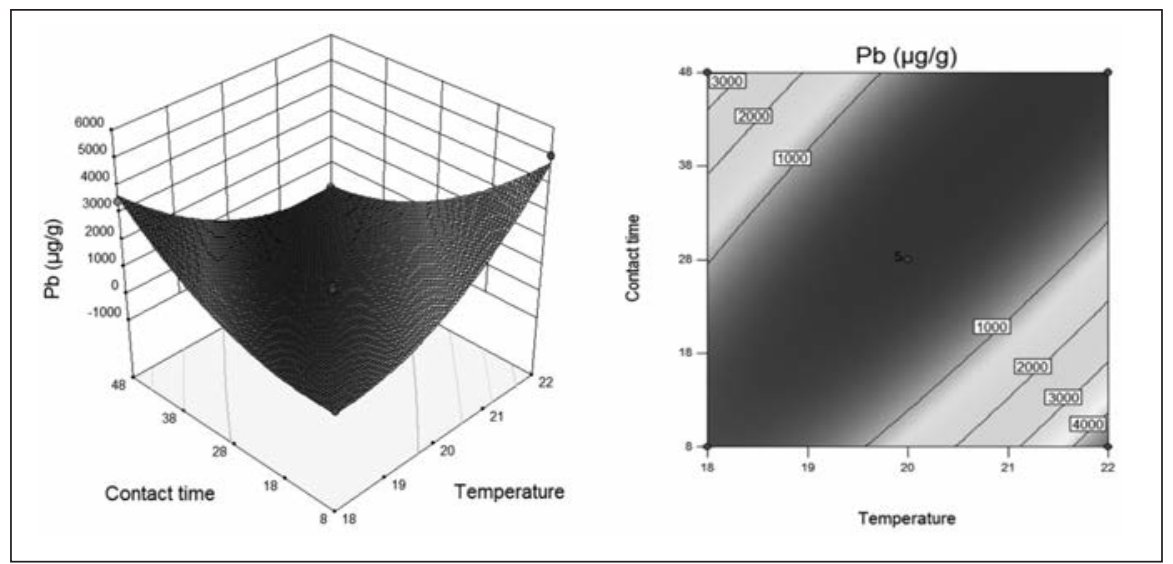

Fig. 2. Effects of contact time and temperature on Pb bioaccumulation.

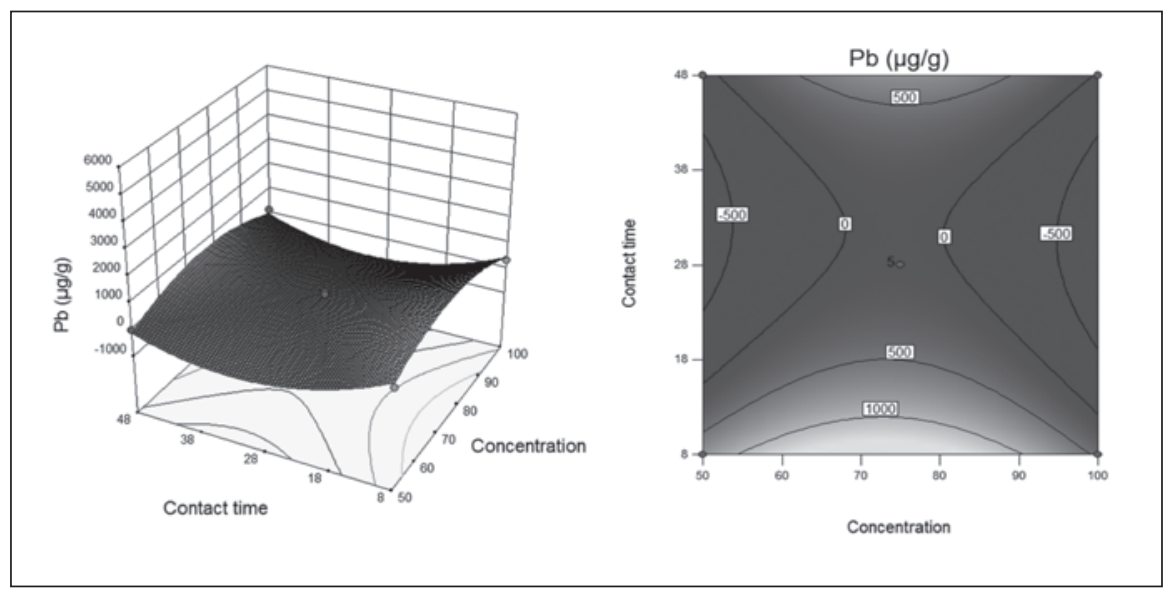

Fig. 3. Effects of contact time and Pb concentration on Pb bioaccumulation.

contact time and $\mathrm{Pb}$ concentration on $\mathrm{Pb}$ bioaccumulation in G. pulex are shown in Figure 3. The bioaccumulated $\mathrm{Pb}$ amount increased with a decrease in contact time until it reached a plateau at 8 hours, indicating that there was further improvement in the bioaccumulated $\mathrm{Pb}$ level.

\section{Confirmation of Experiments}

Under the optimized conditions (temperature $22^{\circ} \mathrm{C}, \mathrm{Pb}$ concentration $75 \mu \mathrm{g} \mathrm{L}^{-1}$, and contact time 28 hours) and to support the optimized data given by numerical modeling, experiments were performed with the parameters as suggested by the model.
Lead bioaccumulation was modeled in G. pulex samples and taken from aqueous (concentrations of $\mathrm{Pb}$ ), dietary (poplar leaves added $\mathrm{Pb}$ ), and exposed samples (29). At the end of the experimental studies it was found that biodynamic parameters contributing to contamination, such as the natural/available living/feeding environment for determining $\mathrm{Pb}$ bioaccumulation, are important factors.

In another study, electron microscopy techniques were used to determine $\mathrm{Pb}$ acetate effects on G. pulex. It was reported that $\mathrm{Pb}$ acetate may induce some ultrastructural changes on hepatopancreatic ceca of the digestive system (39). Lebrun et al. (40) also researched waterborne $\mathrm{Cu}$ influence on the digestive metabolism of G. pulex. Wang and Zauke (31) discussed bioaccumulation of metals in the amphipod Gammarus zaddachi and its relationship to the permeable body surface area.

\section{CONCLUSION}

The Box-Behnken experimental design combined with RSM was successfully fitted for $\mathrm{Pb}^{2+}$ determination and the results revealed that the G. pulex is suitable for biomonitoring studies for $\mathrm{Pb}^{2+}$ bioaccumulation. This aspect is additionally supported by a net accumulation strategy found for $\mathrm{Pb}^{2+}$ bioaccumulation. Furthermore, this model and the amphipod can serve as a predictive tool to evaluate the quality of the environment in terms of $\mathrm{Pb}^{2+}$ contamination in aquatic systems.

According to research by the authors, no report has been published on the relationship between the Box-Behnken model parameters and heavy metals bioaccumulation in G. pulex. This study supports the idea that $\mathrm{Pb}^{2+}$ bioaccumulation in G. pulex is mainly dependent on three factors: temperature, metal concentration, and contact time. The results present a successful 
model verification for $\mathrm{Pb}$ bioaccumulation and provides information for $G$. pulex as a biomonitor. When this approach is compared to other models and conventional studies, it ensures a convenient operation. In conclusion and based on the results, the amphipod G. pulex is suitable for biomonitoring studies and the Box-Behnken approach applied for metal exposure concentrations can serve as a powerful tool to predict and assess environmental quality. This study can make a breakthrough in identifying biomonitors necessary to evaluate the bioaccumulation potential in aquatic systems.

Received June 3, 2018.

\section{REFERENCES}

1. J.F. Peng, Y.H. Song, P. Yuan, X.Y. Cui, and G.L. Qiu, J. Hazard. Mater. 161, 633 (2009).

2. A. Akcil, C. Erust, S. Ozdemiroglu, V. Fonti, and F. Beolchini, J. of Cleaner Production 86, 24 (2015).

3. P. Cretì, F. Trinchella, and R. Scudiero, Environ. Monit. Assess. 165, 321 (2010).

4. A.H. Sulaymon, B.A. Abid, and J.A. Al-Najar, Chem. Eng. J. 155 (3), 647 (2009).

5. M.I. Castro-González and M. Méndez-Armenta, Environ. Monit. Assess. 26, 263 (2008).

6. Y. Li, F. Liu, B. Xia, Q. Du, P. Zhang, D. Wang, ... and Y. Xia, J. of Hazard. Materials, 177(1), 876 (2010).

7. M.A.P. Cechinel, S.M.A.G. Ulson de Souza, A.A. Ulson de Souza, J. of Cleaner Production. 65, 342 (2014).

8. M.M.N. Authman, M.S. Zaki, E.A. Khallaf, H.H. Abbas, J. Aquac. Res. Development. 6, 4 (2015).

9. G. P. Zauke, and G. Petri, Lewis Publishers, Boca Raton, USA, 73 (1993).
10. P.S. Rainbow, D.J.H. Phillips, M.H. Depledge, Mar. Pollut. Bull. 21, 321 (1993).

11. A. Viarengo, and J.A. Nott, Comp. Biochem. Physiol. C Comp. Toxicol., Part C., 104, 355 Mini review (1993).

12. U. Borgmann, W.P. Norwood, Can. J. Fish Aquat. Sci., 52, 864 (1994).

13. G.P. Zauke, G. Petri, J. Ritterhoff, H.G. Meurs, 27, 207 (1996).

14. J.C. McGeer, K.V. Brix, J.M. Skeaff, D.K. DeForest, S.I. Brigham, W.J. Adams, A. Green, Environ. Toxicol. Chem. 22, 1017 (2003).

15. P.S. Rainbow, Environ. Internat. 33, 576 (2007).

16. M. Rinderhagen, J. Ritterhoff, G.P. Zauke, Trans Tech Publications Scitech Publications, Environ. Res. Forum. Vol. 9. Uetikon, Zürich, 161 (2000).

17. B. Clason, B. Gulliksen, G.P. Zauke, Sci. of the Total Environ. 323, 227 (2004).

18. J.P. Besse, M. Coquery, C. Lopes, A. Chaumot, H. Budzinski, P. Labadie, O. Geffard, Water Res. 47, 650 (2013).

19. J.D. Lebrun, O. Geffard, N. Urien, A. François, E. Uher, L.C. Fechner, Sci. Total Environ. 511, 501 (2015).

20. V. Felten, G. Charmantier, R. Mons, A. Geffard, P. Rousselle, M. Coquery, J. Garric, O. Geffard, Aquat. Toxicol. 86, 413 (2008).

21. O. Dedourge-Geffard, F. Palais, S. Biagianti-Risbourg, O. Geffard, A. Geffard, Chem. 77, 1569 (2009).

22. U. Borgmann, W.P. Norwood, D.G. Dixon, Environ. Pollut. 131(3), 469 (2004).

23. S.N. Luoma, P.S. Rainbow, Environ. Sci. Technol. 39, 1921 (2005).

24. I. Worms, D.F. Simon, C.S. Hassler, K.J. Wilkinson, Biochimie. 88, 1721 (2006).

25. M.N. Croteau, and S.N. Luoma,

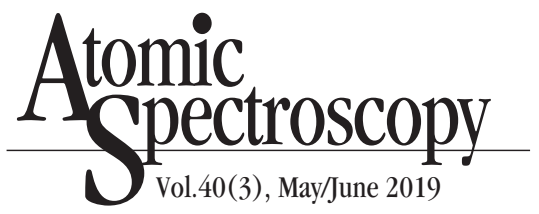

Environ. Sci. Technol. 41, 3140 (2007)

26. I. Komjarova, and R. Blust, Environ. Toxicol. Chem. 28, 1739 (2009).

27. B. Pellet, O. Geffard, C. Lacour, T. Kermoal, C. Gourlay-Francé, M.H. Tusseau-Vuillemin, Environ. Toxicol. Chem. 28, 2434 (2009).

28. J.D. Lebrun, M. Perret, A. Geffard, C. Gourlay-Francé, Ecotox. 21, 2022 (2012).

29. R. Hadji, N. Urien, E. Uher, L.C. Fechner, J.D. Lebrun, Ecotox. and Environ. Safety. 129, 257 (2016).

30. J. Kahle, and G.P. Zauke, Aquat. Toxicol. 59,115 (2002).

31. X. Wang, and G.P. Zauke Hydrobiologia. 151, 11 (2004).

32. L. Franco, D. Romero, J.A. García-Navarro, M. Teles, and A. Tvarijonaviciute, Marn. Poll. Bul. 102(1): 30 (2016).

33. C. Vellinger, E. Gismondi, V. Felten, P. Rousselle, K. Mehennaoui, $M$. Parant, and $P$. Usseglio-Polatera, Aqua. Tox. 140: 106-116 (2013).

34. A. Geffard, H. Sartelet, J. Garric, S. Biagianti-Risbourg, L. Delahaut, and O. Geffard, Chem. 78(7): 822. 2010.

35. K. Mahalik, J.N. Sahu, A.V. Patwardhan, B.C. Meikap, J. Hazard. Mater. 182(1), 603 (2010).

36. D. Krishna, and R.P. Sree, International J. of App. Sci. and Eng, 12(3), 157 (2014).

37. C.I. Weber, (Ed.). US Environ. Protec. Agency, (p. 197). (1991).

38. M. Ince, and O. Kaplan Ince, Atomic spect. 38(6), 200 (2017).

39. M. Kutlu, A. Düzen, C. Bayçu, A. Özata, Environ. Toxi. and Pharma. 12(3), 181 (2002).

40. D. Jeremie, M.P. Lebrun, A. Geffard, and C. Gourlay-France, Ecotox. 21, 2022 92012). 